\title{
Research on the Novel Business English Education Mode based on Feedback Learning and Interactive Teaching Method
}

\author{
Weiping Wang \\ Wuhan International Trade University,Optical Valley the 2nd.Road No. 88, \\ East Lake New Technology Development Zone, Wuhan City,Hubei Province ,430205
}

\begin{abstract}
In this paper, we conduct research on the novel English education mode based on feedback learning and interactive teaching method. Business English, which is based on general English, from the angle of English language features of text represents connotation of business English vocabulary expressed more, word ambiguity phenomenon is relatively common, meaning and pragmatic choice depends on the context. Our research starts from the analysis of the novel education pattern with the feedback learning and interactive teaching integration. Our education mode will let the students and the teachers interact with others and encourage the better participation passion that is meaningful.
\end{abstract}

Keywords- English Education, Feedback Learning, Interactive Teaching, Learning Mode.

\section{Introduction}

With the continuous reform and development of higher vocational English teaching, English teaching in modern higher vocational colleges teaching content, teaching idea, or on the teaching methods are becoming mature, more and more manifests the "practical give priority to, for sufficient degree" and "cultivating students' ability to use the language" principle. When the student through the general English teaching has mastered the basic English knowledge and skills, according to the principle of the need analysis to the student, and selected according to the results of the analysis of the teaching contents and methods, students can quickly obtain professional communication ability to make their English language ability to reach the level of behavior, rather than a long stay in cognitive level.

Teachers, textbooks, students are interdependent relations of three dimensional in college English teaching. Accordingly, the relationships of three aspects could be generally summarized as follows. (1) The student emotion. Student as cognitive, emotional information dynamic network in one of the most important, the student emotion is a very important influence on the quality of college English teaching. Researchers found that the learner's emotional state that will directly affect their learning behavior and learning effect. (2) Teachers' emotional. College English teaching, while the teacher of the cognitive information and emotional information flow of a highly dynamic network, teachers' emotion to the whole quality of college English teaching are ineffable importance. (3) In the emotions of teaching materials. Teachers only from two aspects of know perfectly well to deal with the teaching material content, the ideological content and affective organically that make the static of the teaching materials, into a dynamic that make students form content of the affective commitment to the teaching material, to improve efficiency of modern foreign language teaching activities, promote the students' quality and harmonious development in an all-round way [1-3].

For college students in China learn English not only learn vocabulary grammar knowledge, but 
also can correctly use the knowledge, master the translation skills in reading, writing, listening and general speaking. Language use ability training is a systematic process, and students of both internal factors and external factors. Internal factors include the students' English learning motivation, emotion, will, cognitive ability, etc., the external factors such as teaching environment, teaching material, teachers' ability. Therefore, in the view of the above problems, the author attempts from the angle of public English and professional English teaching cohesion, the existing in the vocational English teaching in higher vocational schools, vocational English teaching in higher vocational colleges, summarized the status quo analysis, and from the institutions, teachers, textbooks, teaching method and the evaluation and so on to discuss how the vocational English teaching and the English teaching cohesion, to attract more attention and discussion. Accordingly, in this paper, we conduct research on the novel English education mode based on feedback learning and interactive teaching method.

\section{Business English}

Technical English assigns single, clear definitions to the words that are being used. It is used by

businesses, educators and technicians

throughout the world.

Private companies have developed programs to meet the English language needs of corporate professionals and technicians

Training in this language format helps multiple users across a diverse business community understand each other on a consistent basis

Figure 1. The General Characteristics of the Business English

\section{The Proposed Methodology}

The Interactive Teaching Method. Constructivism advocates interactive teaching is kind of method through the interaction between teachers and the students to guide the students through self-questions, summary, clarification and prediction steps, monitoring the learning process, in the process of basic interactive teaching between teachers and students construct knowledge system of teaching ideas.

From the point of view of language learning is the basic rule, the main body is a student of college English teaching practice, the students are truly act as the main body of the teaching and traditional teaching model for students' personality characteristics and the actual demand do not give sufficient consideration, to some extent as ignored the students' main body role. Piaget pointed out that: in the constructivism learning theory put forward by the student's learning process is much more than just done through passively accept input from the outside, students need to actively construct the cognitive subject and knowledge significance as is also actively construct the learning of the active knowledge, learners' the ability to construct knowledge meaning in the process of individual learning [4-5].

The author thinks that, in interactive English teaching, affect the students' language understanding and expression of the specific factors have the following several aspects. (1) The teacher's evaluation factors. According to the intermediary role of the Fiore Stan theory, teachers' role in language classes should not be limited to provide the task and promote the words of the interaction between learners, it should be through the language between them to create a better learning environment for learners. (2) Personality and confidence factor. In the interactive teaching, has the self-confidence is not afraid of the mistakes, actively participate in interactive activities; On the contrary, the less confidence always doubt his ability and to meet a language comprehension obstacles, may think that communication is difficult because their level difference, caused by a lack of ability. (3) Social background factors. The background knowledge in communicative interaction, if the disparity is not big, said people talk about the 
topic and content are more likely to be receptive people understood and then communication can proceed smoothly with the prior accumulation of the communication potential.

Modern teaching idea that the purpose of English teaching is the basic knowledge, basic skills and the personality emotional protection development in teaching process, realize harmony. In established on the basis of equality between teachers and students emotion, adopt the way of a variety of mutual cooperation, optimize the relationship between teacher and student, student that promotes the student individuality full, active and lively. Above all, the interactive teaching mode for the obligations of the higher education, students are actively curious rather than the passive educatees student needs are the decisive factors in teaching mode to accept the teaching content, students are active selectors rather than passive recipients, students interest and active learning the enthusiasm is the key to decide the teaching effect in the teaching process, students are active participants rather than passive bystander. In the following figure two, we demonstrate the principles.

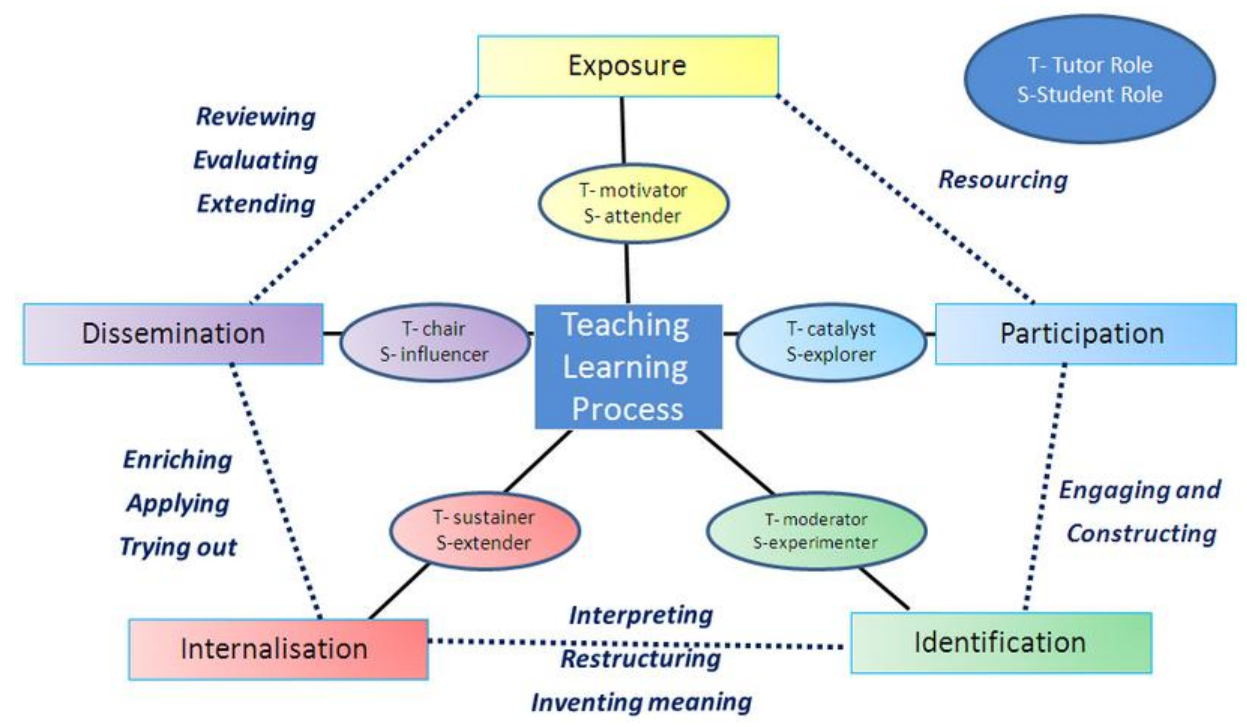

Figure 2. The Interactive Teaching Method and the Corresponding Procedures

The Feedback Learning Concepts. The role of feedback in learning has always been one of the research topics of learning theorists. With the development of learning theory, the understanding of basic connotation and function of the feedback has been changed. Behaviorists emphasize feedback external reinforcement for learning. In the teaching environment, feedback usually refers to in order to improve and improve the students' learning and the information sent back a learning task completion.

Feedback can be written or oral, can also be a sound or silent can be the right affirmation, also can is error correction that can take place between teachers and students and also can take place between students, students and this article mainly refers to the feedback of feedback between teachers and the students. In the following figure, we illustrate the corresponding concepts [6-7]. 


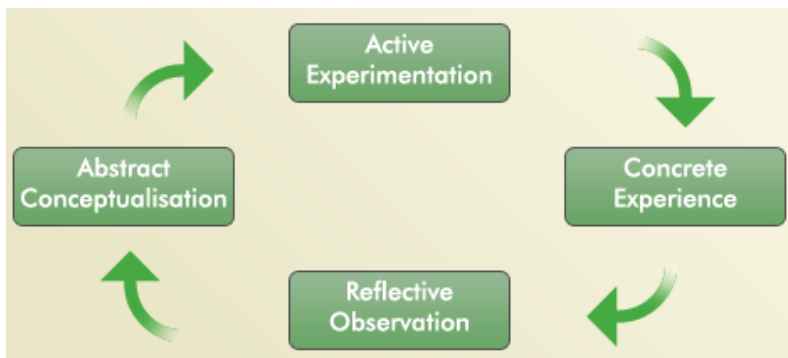

Figure 3. The Feedback Learning and the Principles

In view of feedback, especially effective feedback is one important part in language teaching, it is necessary to analyze different teaching method view of feedback, understand people understanding of feedback. (1) Skill instruction: if we want to successfully acquire a skill, learners need feedback in order to understand their performance; Therefore, faithful assessment of importance of self-evident. (2) Method: try to avoid negative evaluation, because it has the function of the "punishment" is not conducive to learning, as easy bruising study enthusiasm. Positive evaluation can strengthen the right reflect, thus improve learning. (3) Humanistic law: the role of the assessment is the key to protect and to promote the learners' individual positive self-image and language learning, so the evaluation should be affirmative or without judgment.

As research on the role of the effectiveness of corrective feedback to affirmation and recently more and more studies to explore the different types of the corrective feedback on the different impact of different aspects of second language acquisition. First of all, its subtle features make it not too much impact on the communication is fluent. In addition, it has enjoyed as is generally thought that, after the errors occur an immediate feedback is very important, because it can help learners to find out the difference of their wrong words and the target structure, that conducive to subsequently give up error correct structure and acquisition. Visible, people understanding of feedback has experienced some of major changes, in connotation by external feedback to the internal feedback, the feedback provided by the learners to passively accept outside to take the initiative to the generate and use the feedback; By external reinforcement on the function and external information source and correction function to the control loop and the monitoring function. From the perspective of the cognitive theory, correction is helpful for learners to verify its assumptions about language learning and thus further adjust relevant knowledge structure or renew. But if stress to correct all the mistakes, in the practice it is difficult to operate, and not in conformity with the actual situation of learners.

The Business English Education. Business English is a kind of social function of basic English variation that is a branch of English for special purposes, is the application of English in business occasions. It involves the technology import, foreign trade, investment, foreign labor service contract with the contract, contract, international finance, foreign insurance, international tourism, overseas investment, the international transport and so on, people engaged in these activities are collectively referred to as the use of English business English [8].

By their nature, the business English is a branch of applied linguistics, linguistics and the applied linguistics as theoretical basis, for the purpose of basic pragmatic services in business communication activities that reflected in the English language and business operations of organic integration.

We can say that the business English includes both on technology import, overseas investment and international transportation in the basic process of practical application, also covers trade data and information, company culture aspects of 
language, such as a business professional knowledge, basic knowledge of English language, habits, national habits, interpersonal relationship and so on, so for the research is of great significance on the level of pragmatic meaning, it is focus on caller the use of the language and the external context for the significance of expression, also research on the hearer said people speak words of decoding and reasoning process. As for the optimized education approach for the modern business English education mode, we should follow the listed guidelines.

- Business English language form, vocabulary and content is closely related to the professional knowledge, it carries the information of business theory and business practice, etc.

- Business English is used in the business class professional term many stems from a Latin or French, some are synthesized from its roots derived or, many terms have the same prefix.

- In business English translation, of the basic source language accurately and faithfully express information in the target language, and be able to let the reader in the reading time, for the information content is equal to the original, namely information equivalence.

- Politeness principle is one of the world any a kind of language is one of the rules of language use, is in the process of language communication is to the opponent's a strategy. In business English, the politeness principle embodied in expression solemn characteristics.

- In business English also exists lots of ellipsis phenomenon compared with general English, business English omitted most of performance in asking defend, rejection, and the commercial advertising and so on.

Based on the mentioned features of the modern business English, we could better modify the basic procedures of the English education. The author after the proposal of the panel can absorb part of the non-English major background of English experts, or the relevant departments of the leadership and experts in the setting of college English teaching objectives, curriculum setting, at least should study more English experts in the field of the different disciplines of the learning English course, college English teaching reform, at the same time for us to listen to their advice.

\section{Conclusion}

In this paper, we conduct research on the novel English education mode based on feedback learning and interactive teaching method. Business English belongs to the English language and literature, in English linguistics and applied linguistics theory as the instruction, which is based on the language, to grasp the general system of language knowledge and basic business knowledge as the goal of English language and the organic combination of the interdisciplinary economic disciplines as is an important function of English language variants. Under this background, we integrate the feedback learning and interactive teaching method to propose the novel methodology on the business English education that will enhance the condition of the contemporary education mode.

\section{References}

[1] Zhu, Wenzhong, and Xuyang Liu. "The Mixed Proportion of Business Knowledge Courses and English Language Courses in Business English Curriculum Design in China." English Language Teaching 7.6 (2014): 154.

[2] Zhu, Wenzhong, Xuping Deng, and Jingyi Li. "A Case Study on Teaching Business Courses in English or Bilingualism with Guangwai as an Example." English Language Teaching 7.9 (2014): 156. 
[3] Zhang, Ling. "Teaching Model design of Business English based on flipped classroom case study." Proceedings of the International Conference on Education, Management and Computing Technology, Hong Kong. 2015.

[4] Evans, Stephen. "Designing email tasks for the Business English classroom: Implications from a study of Hong Kong's key industries." English for Specific Purposes 31.3 (2012): 202-212.

[5] Schweigert, Francis J. "Social Responsibility as a Matter of Justice: A Proposal to Expand Business Ethics Education." Understanding Ethics and Responsibilities in a Globalizing World. Springer International Publishing, 2016. 229-246.
[6] Gill, Judith, and Deborah Tranter. "Unfinished business: re-positioning gender on the education equity agenda." British Journal of Sociology of Education 35.2 (2014): 278-295.

[7] Spencer, J. "Policy, business and ICT: a study of the growth and decline of private vocational training providers in the education/migration industry in Australia." (2014).

[8] Nygaard, Claus, Nigel Courtney, and Clive Holtham. "Effectiveness in higher education demands innovations in teaching that progress beyond transmission." Beyond Transmission. Libri Publishing, 2014. 